\title{
Alienated Modernity in Post-Independence Indian English Fictions
}

\author{
Salar Mahmud Muhamad Salih
}

English Dept., College of Education, University of Garmian, Kalar, Kurdistan Region, Iraq Email: salar.mahmood@garmian.edu.krd

\section{Abstract}

The study hypothesizes the existence of impacts of Western culture through English colonialism and Language on Indian life which caused an alienated dilemma in embracing the modernity, and that opposes the universal understanding that considers accepting modernity by the colonized people is very easy and a matter of time! In fact in the era of globalization, no society can resist the influence of alien cultures, but still some regions incapable of being familiarized with it. Indian English fiction refers to the body of work by writers in India who write in English language and whose native or co-native language could be one of the numerous languages of India. It is also associated with the works of members of the Indian diasporic fiction writers, such as Anita Desai (b.1937), Raja Rao (1908-2006), Arundhati Roy (b.1961), Salman Rushdie (b.1947), and Amitav Ghosh (b.1956).

The study, thus, tries to tackle the selected quotes from the fictions of above named authors whom attempt their efforts to depict the postcolonial emphasis on the process of colonialization and the record of a strong resistance to the masters of the colonized societies with the insisting on contemporary realities of life, besides the accepting and assimilating of some to adopt the modernity as a new traditional culture which accompanies by certain events. The study also adopts Edward Said's theory of Orientalism to go through the topic in uncovering its hypotheses, and it follows the MLA style to the process of documentation as well.

Keywords: Post-colonialism, post-Independence, alienated, dilemma, tradition, modernity, Indian culture.

\section{Introduction}

Indian (Traditions with possible Modernity) are the resultants of vital historical processes; they actually form the structure of Indian culture. These traditions relate to several ideologies such as Buddhism, Islam, and Christianity, tribal and western modernity.

Post-Independence (colonial) literature is regarded the literature of those countries that were colonized, mainly by European countries. It mostly addresses the questions relating to the political and cultural independence of formerly yielding 
people, and major themes such as adapting through forcing new culture, racialism, and colonialism are discussed. Frantz Fanon (1925-1961) asserts that colonialism was the reordering of the world of indigenous (native) people, and he also considers the anxiety to recover a tidy pre-colonial culture as a reason behind motivating native intellectuals of having a decolonized attitudes of anti-colonial nationalism. Postcolonial writers appeared from Africa, South Asia (India), the Caribbean, South America and other places; they observed that it was the exact time for postcolonial writers to tell their own stories, from their own perspective through decolonization (Abrams 277).

Postcolonial, is a term, denotes to the period when the colonized states attained freedom from European colonization. It tackles the impacts of colonialism on cultures and societies during the post-independence time. Colonialism, also, considered a cultural controlling by the colonizer that shaped a kind of serious struggle concerning self-identification to anti-imperialistic protest which sometimes turn the postcolonial literature into a resistance literature for both the colony and the colonized, post-independence literature aims at exploring the inevitable clash as a result of the colonial and postcolonial encounter that led to have a hybrid community accompanied by a state of in-betweeness (Ashcroft et al 20).

Post-colonialism, in literature, mainly displays the conflicts of identity and cultural belonging. Colonial powers invaded foreign states and ruined main parts of native tradition and culture; moreover, they repeatedly replaced them with their own ones. Religious-ethnic conflicts often took place when countries became independent and faced the difficulties of developing a new nationwide identity and self-ruling. The confrontation of these countries was to achieve an individual way of proceeding to call their own in a time that they were not capable of getting rid of the Western way of life from the day of their independence and so far (Nils 4).

Edward Said (1935-2003) showed in his Orientalism the image of cultural differences, according to him, Theory of Orientalism provides a rationalized understanding for European colonialism in which "the West" constructed "the East" as extremely different and inferior; it also involves a way of observing the other that justifies a continuous system of domination. Said, further, recalls Orientalism as the West's patronizing representations of "The East" including the societies and people who inhabit the places of Asia, North Africa, and the Middle East. It is tied to the imperialist societies who produced it and makes much confusion in the process of affected and being affected by the suppressed nations (Said 31). 


\section{Colonial and Postcolonial (Post-Independence) India}

In 1756, the "British East India Company" was established, and then the British colonialists started controlling most parts of India while ruling the significant big cities such as Calcutta, Madras and Bombay as the main British bases. In 1857, the first great rebellion witnessed in the north of India, the incident is also named "First war of Indian Independence". This was the first time that Indian people revolutionized in huge numbers against the rule of the British in South Asia, the rebellion failed and the British colonialists went on their rule (Nils 6).

The peaceful resistance was really started well by Mahatma Gandhi (1869 - 1948) and Jawaharlal Nehru (1889-1964) against British colonial rule which eventually led to independence in 1947. India's nationalism before independence was a matter of grief and mourning. Thus, most of the writers delineated the difficult unreal world that was relied on the western modernity. However, the titanic Indian culture of the past does not go off completely, and with the independence of the country, the traditional culture of the past surely disintegrated due to modernistic experimentations. Further, the industrial and scientific advancement throughout the country after independence also had an impact on Indian post-independence literature generally and fiction strictly (Bhabha 89).

As Indian literary fictions, after Independence, mainly dealt with the traces of decolonization, so most of the literary works in the post-colonial period presented the social, cultural, and political states of the country. Besides, the identity crisis emerged in the literary writings, and the age counted as 'dark modernism'. The particular identity crisis of the writers and the clash between traditional cultures and western modernity is widely experienced in the writings during those days. The concept of experimentation also progressed under the western influence. It emerged as a chase for new values, one of the greatest obstacles in the way of the growth of the home literature of India after independence was the dominance of double-standards including both local and away influences (Singh 11).

\section{Indian Diasporic and Hybrid Literature}

Diaspora, according to Webster, is a movement of migrated, scattered people settled far from their ancestral homelands. Literature of the Indian diaspora claims a theoretical structure based on trauma, mourning/impossible mourning, specters, identity, travel, translation, and recognition, also 'migrant identity' denotes to any ethnic that enclosed in a nation-state that realizes itself, consciously or 
unconsciously, as a group in displacement. And the gist of the diasporic writing is the obsessing presence of India and the shared melancholy of personal loss that produce the aesthetics of 're-worlding' causing the unification of this body of literature that includes postcolonial, exile, and immigration sense. Rushdie, Rao, Desai, and Ghosh are among the outstanding Indian diasporic writers (Kumar 8).

Hybridity is regarded the forming of new transcultural forms within the contact zones which considered a locale of complex and crooked actions and it facilitates the process of translation between cultures, and these all resulted by colonization. Amita Ghosh, Sujata Bhatt, Mukherjee, and Vikram Seth are counted as famous hybrid Indian writers. Further, when the elements of the British culture and identity are applied to an individual own sense of oneself, it will be a kind of hybrid character, and to be a special member of a colonized culture is to counter the western generalizations of that culture through a stereotype formed to fix groups in a place, refusing their own sense of identity most of times (Anand 22).

\section{Dilemma of Alienated Modernity.}

The theme of modernity emerged in the Indian context along with different lines, the need was to create something new even if it's the imitations of western modernists existed as a challenge to understand their own realities, and a new language was appeared to articulate their own historical state. The imitation of the west, the decadence of canons, and the disappointment of the middle class psyche are some of the characteristics of Indian modernity which became a way of documenting the dehumanization of society in India after independence. In western concept, modernity is regarded a breaking away from rules, traditions, and conventions for implying new ways of considering man's position and functions in the universe while Indian modernism is seen as a phenomenon or value, and not a completely unrelated one without pointing to the past or the future (Kalia 144).

The Indian mind does not denote to a tradition of the past or a tradition of the culture of the past, it believes that what exists today is tradition and culture. This will create a biculturalist sort of life which was recognized by Mahatma Gandhi $(1869-1948)$ as he states:

Everyone of the Indians who has achieved anything worth mentioning in any direction is the fruit of western education, at the same time, whatever reaction for the better he may have had upon the people at large 
was due to the extent of his eastern culture (75).

Also, in a culture like the Indian, the past does not vanish; it goes on making paradigms for the present. The present develops from the past and both the past and the present change together, but it didn't last longer since the rhythm ruined due to the modernistic experimentation in the early fifties forming its power from the west (Hicks 97).

Indian post-independence fiction Writers like Rushdie, Raja Rao (1908-2006), etc attempt at discovering the Indian identity through their fictions set up mostly in rural settings. These writers pursued their tradition that disclosed the dialectics of continuity and change rooted in it. They made an effort to retrieve, rediscover and redefine elements of culture in a creative way, by a return to pride in roots, while looking ahead. The certain identity crisis including the struggle between traditional Indianness and western modernity is noticeable in the writings of the major literary areas in India at that time (Ashcroft et al 78).

Raja Rao (1908-2006), the Indian fictionist who in his fiction The Serpent and the Rope (1960), states the condition of expressing one's own social and cultural heritage or submitting one's native feeling and experience to an alien (odd) language (English), he remarked:

We cannot write like the English, we should not.

We cannot write only as Indians. We have grown to

look at the large world as a part of us. Our method

of expression therefore, has to be a dialect which someday prove to be as distinctive and colorful as

the Irish or the American.

So, they used English language as a dynamic medium to uncover the complicated Indian Reality including native scenes and sentimental, rituals, customs, etc. They were not completely able to register the transform from the English literary use of metaphor to locale range and variety via the literary history of post-independence Indian societies (14).

Salman Rushdie, the most outstanding Indian Post-Independence fiction writer, expresses his own view of how English language no longer is abided to be the mere possession for English people and that was only some time ago, he further says:

What seem to me to be happening is that those 
people who were once colonized by the language

are now rapidly remaking it, domesticating it, becoming

more and more relaxed about the way they

use it, assisted by the English language's enormous

flexibility and size, they are carving out large

territories for themselves within its frontiers (64).

Rushdie, in another view, tries to depict some aspects of dilemma of the migrant or a decolonized citizen who searches for an identity in a place where he/she does not relate to. He, further, asserts that the roots are not always something we are born with but they give the choices that made throughout our life. Rushdie, also, stresses the issues of migrant or colonized citizen that he/she must change and adapt the new community, grow new roots, learn how to speak a new language, and ought to have a double identity which is made through progressive adaptation (Toma 123). He believes that the migrant or the colonized citizen may lack or have the power to create new world as imaginary homelands for him/herself, although the process of migration leads rarely to lose the sense of belonging to the homeland and the identity, but it offers the chance to recreate another space to inhabit. He compares the migration as a matter of translation since it's a moving out of origins and relocating into a new space for creating an imaginary homeland (Ibid 124).

In Midnight's Children, Rushdie, by the help of the traditional oral story, summons Indian national life, and there history offers an able medium for his demands for roots and supplies a perfect human dimension to history. In the fiction, Saleem Sinai (The narrator and main character or the protagonist) displays his alienated dilemma of suffering when he lost his family home in India and shifted to Pakistan. Saleem owns an encyclopedic identity which attempts to get the whole universe as it stated by the character himself:

I am the sum total of everything that went before me, of all I have been seen done, of everything done to me.

I am everyone everything whose being-in-the-world affected was affected by mine. I am anything that happens after I am gone which would not have happened if I had not come (440).

Thus, the protagonist confirms the disorder of the recent world and the fact that everything in the universe is belonged to everything. And he delineates the trauma of a hybrid identity so as to stick to the reality he lived as he states " there is a hole 381 | acadj@garmian.edu.krd Vol.5, No.4 (August, 2018) 
in the center of me", due to the falling apart of fragments that he was made up from (192).

Rushdie goes further in his another fiction Shame to draw the image that people always need to belong to a place or a culture, and he managed to acclaim that personal identity is the outcome of the chaos of modern community shaped by globalization and border crossing and inbetweenness. He illustrates, in the fiction, the feeling of both not belonging or belonging to more than one culture by stating:

What is the worst thing about colonized, displaced, and migrant person? I think it is their hopefulness.

And what is the worst thing? It's the emptiness of one's baggage. We have come unstuck from more than one land and floated upwards from history, from memory, from time (91).

Anita Desai (b.1937) is another post-independence Indian fictionist who states in her fiction Cry, the Peacock the society's need to repossess its own past and overcome the modern alienated atmosphere since they write with an extreme awareness to reconsider their identity in the terms of their roots. They have to strife with a complicated situation in which indigenous elements stand against important objects. In her fiction, a young girl obsessed by the dilemma of a childhood prophecy of disaster, and her rootlessness increases more when her brother writes to her " Without root, one cannot grow to any height"(140). This condition makes the young girl in her dilemma of how to find herself in her previous traditional culture so as to comprehend the adaptation of the modern one through the difficulties of being alienated in recent moments, Desai states through the young girl in the fiction:

All order is gone out of my life, no peace,
nothing to keep me within the pattern
of familiar, everyday living and doing that
becomes those whom God means to live
on earth. Thoughts come, incidents occur,
then they scattered, and disappear.
Past, present, future. Truth and Untruth.

The pattern for an order of lines and designs, a symmetry....has deserted my own life.

Strangers surround me (179). 
Arundhati Roy (b.1961) is among the post-independence fiction writers that achieved her absolute fame through her fiction The God of Small Things. She considers the little events and the normal things as important as the huge affairs to show how modernity faced impossible times to be adapted at its very early stages. Roy's conception of history is evidenced in her fiction as she says:

Perhaps it's true that things can change in a day.

That a few dozen hours can affect the outcome of whole lifetime. And that when they do, those few dozen hours, like the salvaged remains of a burned house, the charred clock, the singed photograph, the scorched furniture must be resurrected from the ruins and examined (32).

Amitav Ghosh (b.1956) is a first-world literary writer who regards the world to be a "global village" where all individuals from different nationalities and cultures reach each another regardless to their race, religion, and culture. He suggests:

Communities like memory are transnational, and the transitional and transnational space occupied by migrants is a transnational one too, not globalized, not between nation-states, but outside them, linking communities across borders through its desire and discourse of material and emotional belonging (37-38).

In his fiction The Circle of Reason, he attaches the aggressive aspects of postcolonial communities with expected hopefulness concerning the possibilities of post-colonial modernity through presenting segments of substituted utopian projects, on the opposite side; the fiction shows the tyrannical sides of modern rationalities and social forms. Moreover, Ghosh draws attention to the artificiality of the east-west binaries of orientalism, and he declares the hybrid and mixed nature of cultures could be sounded through language as well, so language might be an element for having the possible difficulties in adapting modernity within a deep rooted traditional culture representing through Indian post-independence fictions. 


\section{Conclusion}

The study concludes that:

1. The alienated protagonists of most of the post-independence Indian English fictions are incapable of adapting modernity easily due to the psychological, social, traditional factors which stand as obstacles to embrace modernity not even by a single character but by the whole community as well. Saleem and other main characters suffer tremendously to attain the globalized modernity and finding a specific new shelter for their own since they relate to everywhere and nowhere.

2. It's also concluded that in Indo-English post-independence fictions, alienation and rootlessness stand as very common themes, and alienated modernity serves as a basic theme and recurrent motif in many Indo-English fictions.

3. Also, the protagonists are regarded as alien figures in their society largely because of their serious trying to build a new country or culture as they are migrants or colonized citizens as a result of the powerful colonizers that apply the disordering to the familiarized realities.

4. Finally, serious attempts could be observed by the Indian fictionists to sketch the confusion, frustration, alienation, disintegration and estrangement of modern man toward receiving the elements of modernity.

\section{References}

Abrams, M.H. "A Glossary of Literary Terms". Canada, WCL. 2009. Print. Anand, M.Raj." Untouchable". London, Penguin Books. 1940. Print.

Ashcroft, B. Griffiths, G. "The Empire Writes Back: Theory and Practice in PostColonial Literatures". London, Rutledge. 2002. Print.

Bhabha, Homi. "The Location of Culture". London, Routledge. 1994.Print.

Desai, Anita." Cry, The Peacock". New Delhi, O.Papers. 1980. Print.

Gandi, Mahatma." The Intimate Enemy: Loss and Recovery of Self Under

Colonialism". Delhi, Oxford University Press. 1993.Print.

Ghosh, Amitav. " The Circle of Reason, Critical Perspective". Delhi, Pencraft International. 2003.Print.

Hicks, Richard. "Understanding Post-Colonial India's Culture". India, OR. 2016. Print.

Kalia, Ravi. "Modernism, Modernization, and Post-Colonial India; A Reflective Essay". India, 2006.Print.

Kumar, Vivek. " Literature of Indian Diaspora". India. 2011. Print.

Nils, Gluck. "Post-Colonial, Definition, Developing, And Examples from India". Turkey, 2008.Print. 
Roy, Arundhati. " The God of Small Things". New Delhi, Indlink. 1997.Print.

Rushdie, Salman. " Imaginary Homeland". India, Penguin.1991.Print.

Rushdie, Salman. " Midnight's Children". London, Penguin. 1991.Print.

Rushdie, Salman. "Shame". USA, Vintage. 1995.Print.

Said, Edward. " Orientalism". New York, Vintage. 1979. Print.

Singh, Shaleen. " Post-Colonial Indian English Poetry". India, Kanpur University. 2009. Print.

Toma, Irina. " Salman Rushdie-The Contemporary Migrant". Romania, JRLS. 2017. Print.

يوخته

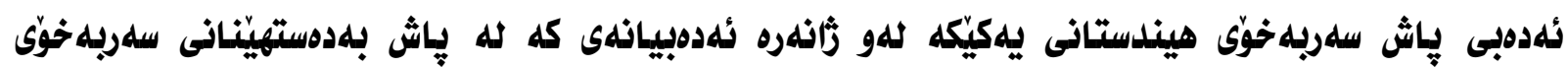

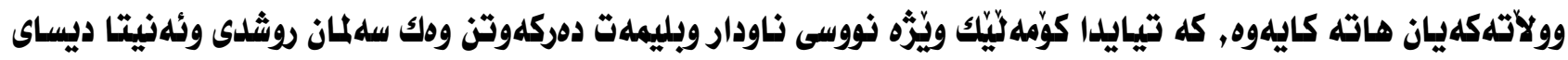

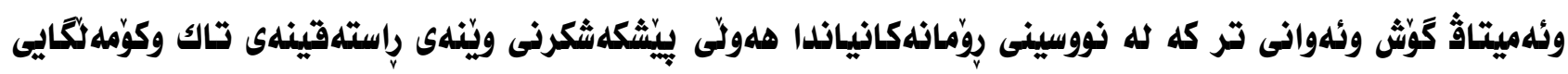

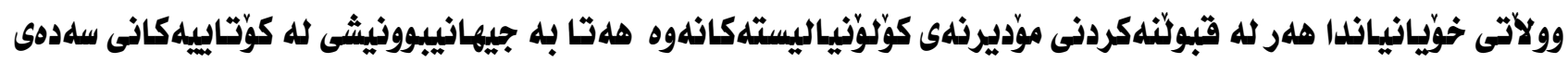

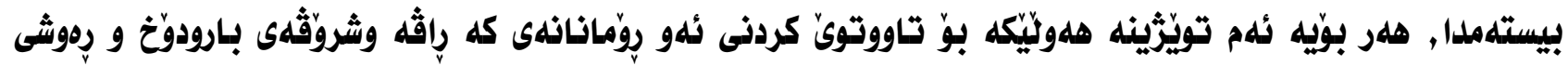

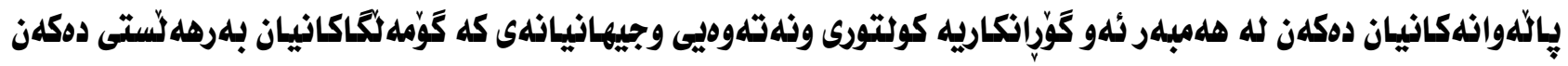

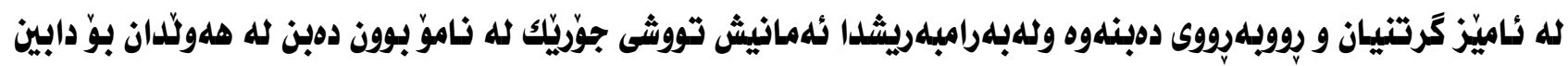
كردنى ئوقُقرديى كله جيهانى مؤديرن دهيخوازيّت. 